\title{
THE EFFECT OF VITRIFICATION DEVICE AND EMBRYONIC STAGE ON SURVIVAL AND DEVELOPMENTAL COMPETENCE OF GABALI RABBIT EMBRYOS
}

\author{
EL-RATEL, I.T. ${ }^{1}$, Y.S. HUSSEIN ${ }^{1}$, SH. M. SHAMIAH ${ }^{1}$, \\ A.E. ABDEL-KHALEK ${ }^{2}$ and A.M. SAEED ${ }^{1}$
}

1. Biotech. Dept., Anim. Prod. Res. Inst., ARC, Egypt.

2. Anim. Prod. Dept., Fac. Agric., Mansoura Univ., Egypt.

(Manuscript received 3 June 2015)

\begin{abstract}
$\mathrm{T}$ he current study aimed to evaluate the effect of vitrification device (straw or cryotop) and embryonic stage (4-8 cell or morula stages) on survivability, normality and in vitro embryo development rate into blastocysts/hatched blastocysts. Total of 24 mature rabbit does of Gabali breed (5-6 months of age, 3-3.5 $\mathrm{kg}$ live body weight) were used in this study as embryo donors. Rabbit does were superovulated by PMSG and hCG. Embryos at 4-8 cell stage were recovered by flushing oviducts 32$43 \mathrm{~h}$ post-mating, while, embryos at morula stage were recovered by flushing oviducts $64-66 \mathrm{~h}$ post-mating. Embryos were vitrified by straw or cryotop. Survival and normality rates were determined. The vitrified embryos were in vitro cultured for 3-5 days to record blastocyst and hatching blastocyst formation rates. Results showed insignificant differences in survival and normality rates of vitrified embryos as affected by embryonic stage, although there were a tendency of higher rates yielded from embryos at morula than at 48 cell stage ( 87.7 and $89.2 \%$ vs. 85.9 and $85.2 \%$, respectively). Survival and normality rates were higher $(P<0.05)$ using cryotop than straw, being 92.1 and $93.1 \%$ using cryotop versus 81.7 and $81.0 \%$ using straw, respectively. Expansion and hatching rates were higher $(P<0.05)$ for vitrified embryos at morula than at 48 cell stage ( 80.0 and $71.5 \%$ vs. 66.0 and $54.0 \%$, respectively) and using cryotop than straw ( 81.6 and 75.3 vs. 63.1 and $48.2 \%$, respectively). The current study could be conclude that using the cryotop method to vitrify rabbit embryos rather than straw method at various developmental stages, particulary at morula stage.
\end{abstract}

Keywords: Rabbit embryo, vitrification, cryotop, survival, blastocyst. 


\section{INTRODUCTION}

Cryopreservation of mammalian oocytes and embryos has been used for several purposes such as to preserve the genes of elite livestock, increase the efficiency of animal breeding, preserve valuable genetically modified animals and endangered species, and use germ cells effectively in assisted reproductive technology in animals and humans (Yasuyuki et al., 2011). In certain cases optimization of cryopreservation protocols for more sensitive embryos is relevant (Chrenek et al., 2014). Vitrification is routinely being used in the artificial reproductive technologies and has become increasingly used than slow freezing method with no or little damage to provide the chance to maintain scientifically important stocks, strains, and lines. Also, vitrification methods have been made possible to store embryos for extended periods and allowed the import and export of embryos and gametes (Habibi et al, 2013).

In rabbits, vitrification technique was used for embryo cryopreservation with improved general efficiency of embryo survival (Chrenek et al., 2014). Several factors were reported on the relative efficiency of cryopreservation, such as embryo culture medium, type and concentration of cryoprotectant and cryopreservation container. Several devices have been developed to produce a small volume of vitrification solution, such as electron microscope grid, open pulled straw, cryoloop and cryotop. Such devices have improved the vitrification and led to the successful production of offspring from vitrified-warmed embryos (Lin et al., 2010).

A cryotop is an alternative device that consists of a thin strip of plastic film (0.4 mm wide, $20 \mathrm{~mm}$ long, $0.1 \mathrm{~mm}$ thin) attach to a hard plastic holder. In the cryotop protocol, embryos are loaded with the use of a glass capillary under the control of stereomicroscope in small volume less than $0.1 \mu \mathrm{l}$ of vitrification medium (Kuwayama et al., 2005a).

According to the changes in cryological properties, e.g. membrane permeability and surface area to volume ratio during embryonic development, vitrification device should be optimized for embryos at various developmental stages (Lin et al., 2011). Cryopreservation of rabbit embryos was reported at morula (Naik et al., 2005), and blastocyst (Lopez-Bejar and Lopez-Gatius, 2002) stages, but higher rates of development were achieved when blastocyst (but not morula) stage embryos were used.

In rabbit, the vitrification of rabbit embryos at pronuclear stage with cryotop yields a higher rate of post-warming survival than either the gel-loading tip or cryoloop. Higher survival rate $(88 \%)$ and development $(52 \%)$ was obtained post- 
warming embryos vitrified at morula to blastocyst stages using a modified open pulled straw method (Lopez-Bejar and Lopez-Gatius, 2002). While, a 91\% survival rate in vitro and $29 \%$ term development (kits/total embryos transferred) after transfer of vitrified embryos at morula stage (Naik et al., 2005).

There were limited reports of vitrification on rabbit embryos at earlier developmental stages (pronuclear to cleavage) and results were generally unsuccessful, except that one study with $94 \%$ in vitro survival and $36 \%$ birth rates was reported on pronuclear stage embryos vitrified by cryoloop (Hochi et al ., 2004).

Therefore, the current study was carried out to evaluate the effect of vitrification device (straw or cryotop) and embryonic stage (pronuclear or morula embryos) on survivability, normality and embryo development rate into blastocysts/hatched blastocysts.

\section{MATERIALS AND METHODS}

This study was carried out at the International Livestock Management Training Center (ILMTC), belonging to the Animal Production Research Institute, Agricultural Research Center, Ministry of Agriculture.

\section{Embryos collection:}

Total of 24 mature rabbit does of Gabali breed (5-6 months of age, $3-3.5 \mathrm{~kg}$ live body weight) were used in this study as embryo donors. Rabbit does were superovulated using injection of 20 IU PMSG/kg live body weight (Foligon, Intervet International B.V., Boxmeer), followed by $40 \mathrm{IU}$ hCG/kg live body weight (Pregnyl, Organon, Nile Co., Egypt), $48 \mathrm{~h}$ later on day of natural mating with fertile bucks belonging to the same breed.

Reproductive tracts of the donors were flushed to embryo collection. The embryos at 4-8cell stages were recovered 32-43 h post-mating (Lin et al., 2010) and pooled as one group, while, embryos at morula stage were recovered $64-66 \mathrm{~h}$ postmating.

Embryos were recovered using flushing medium in Petri dish. The composition of the flushing medium was phosphate buffer saline (PBS) supplemented with $0.2 \%$ $(\mathrm{w} / \mathrm{v}$ ) of bovine serum albumin (BSA) and antibiotics (100 IU penicillin and $100 \mu \mathrm{g} / \mathrm{ml}$ streptomycin, Sigma Chemical Co., St. Louis, Mo, USA).

The recovered embryos were counted and evaluated morphologically under inverted microscope and washed twice in PBS supplemented with $0.2 \%$ BSA and antibiotics. All recovered embryos at 4-8 cell or morula stages were cryopreserved by vitrification method (cryotop or straw). 
Total of 416 rabbit embryos were used 105 and 100 at 4-8 cell stages as well as 108 and 103 at morula stage for straw and cryotop, respectively.

\section{Embryo vitrification:}

A basal medium (BM) containing PBS supplemented with $20 \%$ fetal calf serum (FCS) and antibiotics (100 IU/ml penicillin and $100 \mu \mathrm{g} / \mathrm{ml}$ streptomycin) was used for vitrification. Vitrification was carried out in two steps: in the $1^{\text {st }}$ step, embryos were pipetted into vitrification solution 1 (VS1) containing BM $+12.5 \%$ (v:v) ethylene glycol (EG) $+12.5 \%$ (v:v) dimethyl-sulfoxide (DMSO) $+0.5 \mathrm{M}$ sucrose) in disposable sterile Petri dish for $2 \mathrm{~min}$. In the $2^{\text {nd }}$ step, the embryos were pipette into VS2 (BM + $20 \%$ (v:v) EG+20\% (v:v) DMSO + $0.5 \mathrm{M}$ sucrose) for $30 \mathrm{~s}$. Then, three embryos were loaded into cryotop with $<0.1 \mu \mathrm{l} \mathrm{VS2}$, and immediately submerged in liquid nitrogen (Habibi et al., 2013). Also, eight embryos were suspended in VS2, loaded in $0.25 \mathrm{ml}$ plastic straws (IMV, L'Aigle, France), sealed and plunged directly into liquid nitrogen for at least 15 days.

\section{Thawing of vitrified embryos:}

Vitrified embryos were thawed by plunging the straw or cryotop into one $\mathrm{ml}$ of thawing solution (PBS $+4 \%$ BSA $+0.33 \mathrm{M}$ sucrose) for $1 \mathrm{~min}$, followed by serial dilutions in $\mathrm{PBS}+0.175 \mathrm{M}$ sucrose solution for $2 \mathrm{~min}$ to remove the intracellular cryoprotectants, then embryos were washed three times in PBS solution for 5 min per time to remove cryoprotectants at $25^{\circ} \mathrm{C}$.

\section{Evaluation of post-thawing embryos:}

Survival rate was calculated based on number of post-thawing recovered embryos, while normal and abnormal number of vitrified embryos (normality rate) was morphologically evaluated based on abnormalities in mucin coat, intact zona pellucida, blastomeres, and refractive cytoplasm.

\section{Embryo culture in vitro:}

The survived viable embryos were in vitro cultured in $100 \mu \mathrm{l}$ drops of tissue culture medium-199 (TCM 199, Sigma) supplemented with $4 \mathrm{mg} / \mathrm{ml} \mathrm{BSA}$ and $50 \mu \mathrm{g} / \mathrm{ml}$ of Gentamicin sulphate under mineral oil in $\mathrm{CO}_{2}$ incubator at $38^{\circ} \mathrm{C}, 95 \%$ humidity and $5 \% \mathrm{CO}_{2}$ in air to develop into the blastocyst stage. Embryos were assessed to record blastocyst and hatching blastocyst formation rates for 3-5 days.

\section{Statistical analysis}

Data obtained from this study were statistically analyzed using a software package (SAS, 2004). Mean differences in survival and normality rates, and development of vitrified embryos at different stages, were performed using factorial design. The significant differences among means were tested using Duncan's Multiple Range Test. 


\section{RESULTS AND DISCUSSION}

\section{Post-thawing survival and normality rates:}

Data presented in Table 1 showed insignificant differences in survival and normality rates of vitrified embryos as affected by embryonic stage, although there were a tendency of higher rates yielded from embryos at morula than 4-8 cell stage ( 87.7 and $89.2 \%$ vs. 85.9 and $85.2 \%$, respectively). However, significant effect of cryodevice was obtained on survival and normality rates, being significantly $(P<0.05)$ higher using cryotop than straw. The survival and normality rates were 92.1 and 93.1\% using cryotop versus 81.7 and $81.0 \%$ using straw, respectively.

The effect of interaction between embryonic stage and cryodevice on survival and normality rates was insignificant, reflecting the highest survival and normality rates of vitrified embryos at morula stage using cryotop device (93.2 and 94.9\%, respectively, Table 1 ).

The present results are higher than those reported by Koprdová et al. (2009) who found that viability of rabbit embryos after short-term storage in liquid nitrogen by straw was $46.16 \%$ and after long-term storage it was $44.1 \%$. Survival of rabbit embryos after devitrification, described in the study of Makarevich et al. (2008) was $58.8 \%$. On the other hand, higher survival rate of mouse embryos than that obtained in the current study was recorded by Zhang et al. (2009), who found that the postvitrification survival rates of vitrified mouse embryos at 2-cell, 4-cell and 8-cell stages were 96, 97 and 97\%, respectively. Also, Yasuyuki et al. (2011) reported that the viability of the canine embryos at 4-cell to 16-cell, morula, and blastocyst stages was 90,50 and $40 \%$, respectively.

In accordance with the present results, Hochi et al. (2004) found higher postthawing survival of rabbit embryos vitrified by cryotop than gel-loading tip and cryoloop. In this respect, Hochi et al., (2004) suggested that cryotop is a better alternative cryodevice than open pulled straw. Kuwayama et al. (2005b) reported that use of a cryotop container improves the survival rate of vitrified-warmed embryos and has advantages over conventional vitrification procedures.

The advantages of vitrification of embryos by cryotop was attributed to using very small volumes of embryo suspension (less than $1 \mu \mathrm{l}$ ). Minimizing the volume of the solution with which embryos are vitrified might result in higher viability of the embryos post-vitrification (Yasuyuki et al., 2011). Also, the vitrification by cryotop prevents chilling injury to sensitive cells (Kuwayama et al., 2005c). Generally, problems with viability of embryos after vitrification can be caused by permeable cryoprotectants presented in vitrification solution (Shaw and Jones, 2003). 


\section{Embryo culture in vitro:}

Results shown in Table 2 revealed significant differences in expansion and hatching rates of vitrified embryos as affected by embryonic stage, cryodevice and their interaction. Expansion and hatching rates were significantly $(P<0.05)$ higher for vitrified embryos at morula than $4-8$ cell stage ( 80.0 and $71.5 \%$ vs. 66.0 and $54.0 \%$, respectively) and using cryotop than straw (81.6 and 75.3 vs. 63.1 and $48.2 \%$, respectively).

The effect of interaction between embryonic stage and cryodevice on expansion and hatching rates was insignificant, reflecting the highest expansion and hatching rates of vitrified embryos at morula stage using cryotop device (91.3 and $84.7 \%$, respectively, Table 2 ).

The present trend of increasing expansion and hatching rate of embryos at morula than 4-8cell stages was reported by Lin et al. (2011), who found that the in vitro development of rabbit embryos at 8-cell and morula stages post-vitrification and warming to expanding blastocyst was 70.1 vs. $91.7 \%$ and hatching blastocyst was 63.7 vs. $86.2 \%$, respectively.

In rabbit, the vitrification of rabbit embryos at pronuclear stage with cryotop yields a higher rate of post-warming survival than either the gel-loading tip or cryoloop. Higher survival rate (88\%) and development (52\%) was obtained postwarming embryos vitrified at morula to blastocyst stages using a modified open pulled straw method (Lopez-Bejar and Lopez-Gatius, 2002). While, a $91 \%$ survival rate in vitro and $29 \%$ term development (kits/total embryos transferred) after transfer of vitrified embryos at morula stage (Naik et al., 2005).

In mouse, Zhang et al. (2009) found that the blastocyst formation rate of the 2-cell embryos was significantly lower than of vitrified 4 cell and 8-cell embryos, suggesting the higher sensitivity of younger embryos. The developmental rates of vitrified 2-cell embryos to the blastocyst and hatched blastocyst stages were 69.4 and $52.6 \%$, respectively, versus corresponding values of 93.3 and $60 \%$ for vitrifiedwarmed 4-cell embryos, 91.1 and $78.4 \%$ for 8 -cell embryos, respectively.

Generally, embryos at morula stage appear to be the most optimal stage for embryo vitrification by cryotop. Therefore, the current study could be conclude that using the cryotop method to vitrify rabbit embryos better than straw method at various developmental stages, particulary at morula stage. 
Table 1. Post-warming survival and normality rates of vitrified rabbit embryos as affected by embryonic stage, vitrification cryodevice and their interaction.

\begin{tabular}{|c|c|c|c|c|c|c|c|c|}
\hline \multirow{3}{*}{ Item } & \multicolumn{4}{|c|}{ Main effects } & \multicolumn{4}{|c|}{ Interaction } \\
\hline & \multicolumn{2}{|c|}{ Embryonic stage (E) } & \multicolumn{2}{|c|}{ Cryodevice (C) } & \multicolumn{2}{|c|}{ 4-8 cell stage } & \multicolumn{2}{|c|}{ Morula stage } \\
\hline & 4-8 cell & Morula & Straw & Cryotop & Straw & Cryotop & Straw & Cryotop \\
\hline Total embryos, $n$ & 205 & 211 & 213 & 203 & 105 & 100 & 108 & 103 \\
\hline Post-warming embryos, $n$ & 176 & 185 & 174 & 187 & 85 & 91 & 89 & 96 \\
\hline Survival rate, $\%$ & $85.9 \pm 0.74$ & $87.7 \pm 0.74$ & $81.7 \pm 0.74^{b}$ & $92.1 \pm 0.74^{\mathrm{a}}$ & $80.95 \pm 1.1$ & $91.00 \pm 1.1$ & $82.41 \pm 1.1$ & $93.20 \pm 1.1$ \\
\hline Normal embryos, $\mathrm{n}$ & 150 & 165 & 141 & 174 & 67 & 83 & 74 & 91 \\
\hline Abnormal embryos, & 26 & 20 & 33 & 13 & 18 & 8 & 15 & 5 \\
\hline Normality rate, $\%$ & $85.2 \pm 0.74$ & $89.2 \pm 0.74$ & $81.0 \pm 0.74^{b}$ & $93.1 \pm 0.74^{\mathrm{a}}$ & $78.82 \pm 1.1$ & $91.21 \pm 1.1$ & $83.15 \pm 1.1$ & $94.79 \pm 1.1$ \\
\hline
\end{tabular}

$\mathrm{a}$ and $\mathrm{b}$ : Means denoted within the same row with different superscripts for each effect are significantly different at $\mathrm{P}<0.05$.

Table 2. Developmental competence of rabbit embryos vitrified at different stages and cryodevice after thawing.

\begin{tabular}{|c|c|c|c|c|c|c|c|c|}
\hline \multirow{3}{*}{ Item } & \multicolumn{4}{|c|}{ Main effects } & \multicolumn{4}{|c|}{ Interaction } \\
\hline & \multicolumn{2}{|c|}{ Embryonic stage (E) } & \multicolumn{2}{|c|}{ Cryodevice (C) } & \multicolumn{2}{|c|}{ 4-8 cell stage } & \multicolumn{2}{|c|}{ Morula stage } \\
\hline & $4-8$ cell & Morula & Straw & Cryotop & Straw & Cryotop & Straw & Cryotop \\
\hline Cultured embryos, $\mathrm{n}$ & 150 & 165 & 141 & 174 & 67 & 83 & 74 & 91 \\
\hline Expanded blastocysts, $\mathrm{n}$ & 99 & 132 & 89 & 142 & 40 & 59 & 49 & 83 \\
\hline Expansion rate, \% & $66.0 \pm 0.79^{b}$ & $80.0 \pm 0.79^{a}$ & $63.1 \pm 0.79^{b}$ & $81.6 \pm 0.79^{a}$ & $59.70 \pm 1.1$ & $71.08 \pm 1.1$ & $66.22 \pm 1.1$ & $91.21 \pm 1.1$ \\
\hline Hatched blastocysts, $\mathrm{n}$ & 81 & 118 & 68 & 131 & 27 & 54 & 41 & 77 \\
\hline Hatching rate, $\%$ & $54.0 \pm 0.83^{b}$ & $71.5 \pm 0.83^{\mathrm{a}}$ & $48.2 \pm 0.83^{b}$ & $75.3 \pm 0.83^{\mathrm{a}}$ & $40.29 \pm 1.2$ & $65.10 \pm 1.2$ & $55.41 \pm 1.2$ & $84.63 \pm 1.2$ \\
\hline
\end{tabular}

$\mathrm{a}$ and $\mathrm{b}$ : Means denoted within the same row with different superscripts for each effect are significantly different at $\mathrm{P}<0.05$. 


\section{REFERENCES}

1. Chrenek, P., Makarevich, A.V. and Kubovičová, E. 2014. Developmental potential of vitrified rabbit embryos. The $2^{\text {nd }}$ International Scientific Conference, Animal Biotechnology, Slovak J. Anim. Sci., 47 (4): 198-201.

2. Habibi, A., Farrokhi , N., Morreira da Silva, F., Hosseini, A., Bettencourt, B.F. and Amidi, F. 2013. Transcript analysis of Heat shock protein 72 and protein 53 of 4-cell mouse embryos following Cryotop vitrification. Czech J. Anim. Sci., 58, 5: 217-226.

3. Hochi, S., Terao, T., Kamei, M., Kato, M., Hirabayashi, M. and Hirao, M. 2004. Successful vitrification of pronuclear-stage rabbit zygotes by minimum volume cooling procedure. Theriogenology, 61:267-75.

4. Koprdová, L., Bauer, M. and Chrenek, P. 2009. Effect of the length of embryo storage in liquid nitrogen on their post-warming survival. Slovak J. Anim. Sci., 42 (4): 196-199.

5. Kuwayama, M., Vajta, G., Ieda, S. and Kato, O. (2005a). Comparison blastocysts. In: Gardner DK, Lane M (eds) ART and the Human Blastocyst, Springer-Verlag, New York, pp. 188- 195.

6. Kuwayama, M., Vajta, G., Ieda, S. and Kato, O. (2005b). Comparison of open and closed methods for vitrification of human embryos and the elimination of potential contamination. Reproductive Biomedicine Online, 11, 608-614.

7. Kuwayama, M., Vajta, G., Kato, O. and Leibo S.P. (2005c). Highly efficient vitrification method for cryopreservation of human oocytes. Reproductive Biomedicine Online, 11, 300-308.

8. Lin, T.K., Su, J.T., Lee, F.K., Lin, Y.R. and Lo, H.C. 2010 . Cryotop vitrification as compared to conventional slow freezing for human embryos at the cleavage stage: survival and outcomes. Taiwan J. Obstet Gynecol, 49: 272-8.

9. Lin, T.A., Chen, C.H., Sung, L.Y., Carter, M.G., Chen, Y.E., Due ,F., Jua, J.C. and $\mathrm{Xu}, \mathrm{J}$. 2011. Open-pulled straw vitrification differentiates cryotolerance of in vitro cultured rabbit embryos at the eight-cell stage. Theriogenology, 75:760768.

10. Lopez-Bejar, M. and Lopez-Gatius F. 2002. Non-equilibrium cryopreservation of rabbit embryos using a modified (sealed) open pulled straw procedure. Theriogenology, 58:1541-52.

11. Lopez-Bejar, M. and Lopez-Gatius F. 2000. In vitro and in vivo survival of vitrified rabbit embryos (abstract). Theriogenology, 53: 259. 
12. Makarevich, A.V., Chrenek, P., Olexikova, L., Popelkova, M., Turanova, Z., Ostro, A. and Pivko, J. 2008. Post-thaw survival, cell death and actin cytoskeleton in gene-microinjected rabbit embryos after vitrification. Theriogenology, vol. 70, p. 675-681.

13. Naik, B. R., Rao, B.S., Vagdevi, R., Gnanprakash, M., Amarnath, D., Rao, V.H. 2005. Conventional slow freezing, vitrification and open pulled straw vitrification of rabbit embryos. Animal Reproduction Science, 86: 329-338.

14. SAS. 2000. SAS Institute Inc. SAS User's Guide, Statistics. Cary, NC.

15. Shaw, J.M. and Jones, G.M. 2003. Terminology associated with vitrification and other cryopreservation procedure for oocytes and embryo. Human Reprod., 6 : 583-605.

16. Yasuyuki, A., Yoshinori, S., Tomoyoshi, Asa., Yoshiko, Y.U., Nanae, K., Natsumi, O., Saori, S., Mohammed, A.A., Maya, O., Yoshiyasu, K., Masafumi, M., Kazuro, M. and Hiroshi, S. 2011. Cryopreservation of Canine embryos. Biology of Reproduction, 84: 363-368.

17. Zhang, J., Cui, J., Ling, X., Li, X., Peng, Y. and Guo, X. 2009. Vitrification of mouse embryos at 2-cell, 4-cell and 8-cell stages by cryotop method. J Assist Reprod. Genet, 26:621-0148. 


\title{
تأثير طرق التجميد بالتزجج والمرحلة الجنينية على معدل الحيوية والكفاءة التنموية لأجنة الأرانب الجبلى لجنى علئل
}

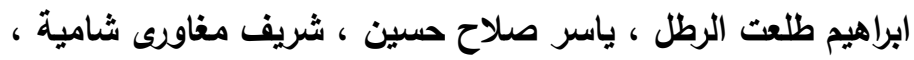 \\ عبد الخالق السيد عبد الخالق ، ايمن مصطفى سعيد
• قسم النكنولوجيا الحبوية- معهد بحوث الانتاج الحبوانسى - مركز البحوث الزراعية. • قسم انتاج الحيوان - كلية الزراعة- جامعة المنصورة.

تهدف هذه الدراسة إلى تقييم تأثير كلا من طرق التجميد منل (straw أو (cryotop) والمرحلة الجنينية (ع- ^ خلايا أو الموريولا ) على معدل حيوية الأجنة وجودتها ومعدل تطورها إلى لى لهن

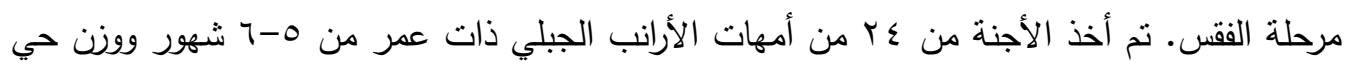

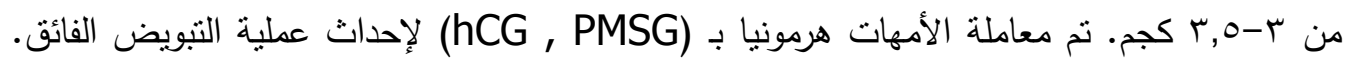

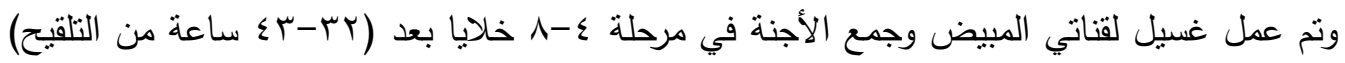

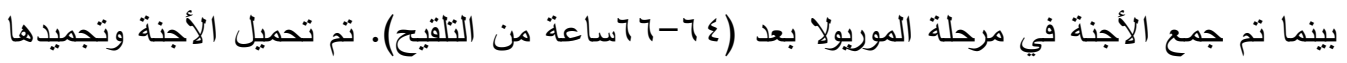

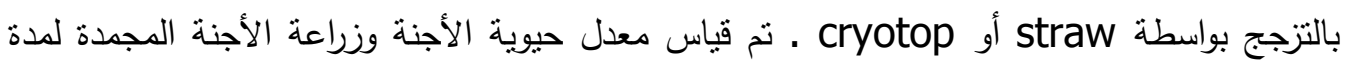

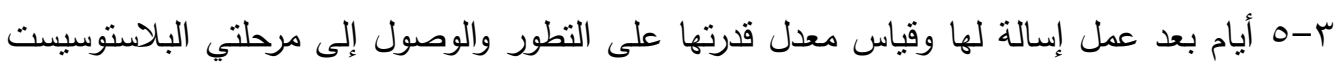

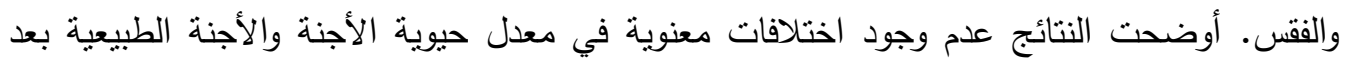
التجميد بالتزجج والتي نأثرت بالمرحلة الجنينية على الرغم من وجود اتجاه لزيادة معدل حيوية الاجنة

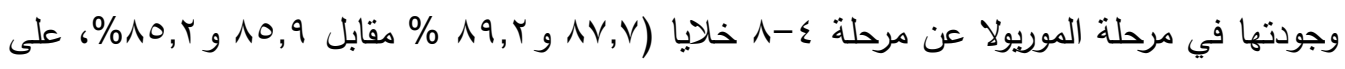
التوالي). بينما وجد أن معدل حيوية الاجنة وجودتها أعلى معنويا (P>0.05) باستخدام

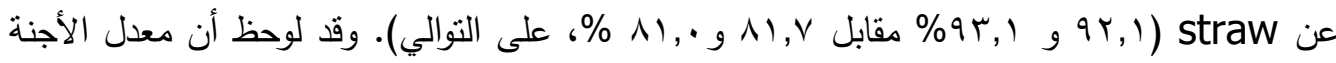
التي وصلت إلى مرحلتي البلاستوسيست والفقس للأجنة المجمدة كانت اعلى معنويا فى مرحلة الموريولا

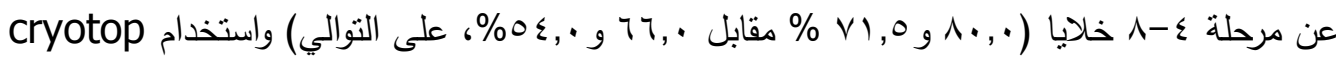

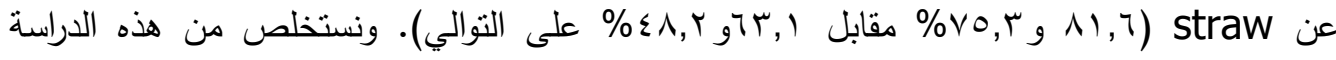
جدوى استخدام Cryotop بديلا عن Straw كوسيلة في تجميد أجنة الأرانب بالتزجج في مراحلها

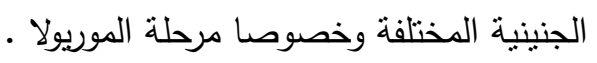

